\begin{tabular}{c|c|c}
\hline \hline & DISEASES OF AQUATIC ORGANISMS \\
Vol. 54: 29-33, 2003 & Dis Aquat Org & Published March 17 \\
\hline \hline
\end{tabular}

\title{
PCR method for detection of largemouth bass virus
}

\author{
John M. Grizzle*, Ilhan Altinok, Andrew D. Noyes \\ Southeastern Cooperative Fish Disease Project, Department of Fisheries and Allied Aquacultures, Auburn University, \\ Auburn, Alabama 36849, USA
}

\begin{abstract}
A polymerase chain reaction (PCR) method was developed for largemouth bass virus (LMBV). This iridovirus can cause a lethal disease of largemouth bass Micropterus salmoides, but also subclinically infects largemouth bass and other species of fishes. Oligonucleotide primers were designed to specifically amplify the major capsid protein gene of LMBV. The protocol for sample processing and PCR provided a method that was more sensitive than cell culture for detection of LMBV in fish. The specific amplification of LMBV also provided an improved method for confirming the identity of cell-culture isolates presumptively identified as LMBV.
\end{abstract}

KEY WORDS: Micropterus salmoides $\cdot$ Detection method · Polymerase chain reaction

\section{INTRODUCTION}

Largemouth bass virus (LMBV) was first isolated in 1991 from Lake Weir, Florida, USA (Grizzle et al. 2002). Plumb et al. (1996) reported the first fish-kill attributed to this iridovirus, and the disease was further described by Zilberg et al. (2000). Although other fish species can carry LMBV, only largemouth bass Micropterus salmoides have been reported to be affected clinically by this virus (Plumb et al. 1996, Hanson et al. 2001).

Cell culture has been used to detect LMBV, which is present at high titers in diseased largemouth bass (Plumb et al. 1996). However, in subclinical infections, virus titers can be near the lower limit of detection for cell cultures (Plumb et al. 1999, Woodland et al. 2002). A polymerase chain reaction (PCR) has been used to confirm that a virus isolated from largemouth bass is an iridovirus (Mao et al. 1999, Plumb et al. 1999), but the current PCR method is not specific for LMBV (Mao et al. 1997, 1999, Bollinger et al. 1999). In addition, simple PCR methods with primers described previously are less sensitive than cell cultures for direct detection of LMBV in this fish (J. M. Grizzle unpubl. data).

In this report we describe methods for sample preparation and PCR that provide an improved method for detection of LMBV in subclinically infected fish. The advantages of this method are (1) specific amplification of LMBV DNA, and (2) detection of LMBV in fish with virus titers below the detection level of the cell-culture method currently used to detect LMBV. The specific nature of this PCR also results in an improved method for identification of presumptive LMBV isolated in cell culture.

\section{MATERIALS AND METHODS}

Sources of fish and viral isolates. Largemouth bass were collected by electrofishing wild fish or by seining hatchery ponds. Channel catfish Ictalurus punctatus, used for negative controls, were obtained from ponds of the Fisheries Research Unit, Auburn University. The LMBV used for the positive control was isolated from a largemouth bass from Santee-Cooper Reservoir, South Carolina (Plumb et al. 1996). Isolates of other iridoviruses were obtained from V. G. Chinchar, University of Mississippi Medical Center (Mao et al. 1997), except for red seabream iridovirus, which was obtained from H. Fukuda, Tokyo University of Fisheries.

Procedures to avoid contamination. Each of the following steps in the method was performed in a separate room: (1) necropsy, (2) DNA extraction, (3) PCR master-mix preparation, (4) DNA quantification and 
addition to the PCR mixture, and (5) PCR reaction and electrophoresis. Laboratory coats, gloves, pipettes, and other supplies were not moved between these rooms. New disposable razor blades, forceps, tongue depressor, and gloves were used for each fish to reduce potential contamination between fish. The PCR mixture included deoxyuridine triphosphate (dUTP) and uracil-DNA glycosylase (UNG) to reduce the possibility that contamination by the PCR product would cause false-positive reactions; UNG degrades uracil-containing DNA at $20^{\circ} \mathrm{C}$ and is inactivated at $95^{\circ} \mathrm{C}$.

Fish sample collection. Similar volumes of swim bladder, spleen, and trunk kidney of each fish were pooled. The portion of the swim bladder collected was the anterio-ventral wall; a tongue depressor was inserted through an incision into the lumen of the swim bladder to support the ventral swim bladder wall during collection of the swim bladder sample. To avoid contamination, organs were trimmed to the correct size while inside the fish and were not allowed to touch the outside of the fish or the work bench. Samples were placed in Hanks' balanced salt solution (HBSS) and kept on ice for up to $6 \mathrm{~h}$. After samples had been weighed, the volume of HBSS was adjusted to obtain a 1:10 dilution of the sample. Channel catfish were presumed to be uninfected by LMBV and were used as negative-control fish, which were necropsied (approximately every tenth fish) along with largemouth bass.

Sample processing. Organ samples were homogenized in a Stomacher 80 (Seward) for $90 \mathrm{~s}$ at high speed. Because LMBV is a cytoplasmic virus, cell nuclei were removed from the organ homogenate by centrifugation $\left(3000 \times g\right.$ for $10 \min$ at $\left.4^{\circ} \mathrm{C}\right)$. The supernatant of each sample was used for cell culture and PCR.

For the DNA extraction, supernatant from infected cell cultures or from centrifugation of organ samples was mixed with an equal volume of lysis buffer $(200 \mathrm{mM} \mathrm{NaCl}, 10 \mathrm{mM}$ Tris- $\mathrm{HCl}$ at $\mathrm{pH}$ 8.0, $1 \%$ sodium dodecyl sulfate, and $50 \mathrm{mM}$ EDTA) and $5 \mu \mathrm{l}$ of Proteinase-K solution $\left(20 \mathrm{mg} \mathrm{ml}^{-1}\right)$ in TE buffer $(10 \mathrm{mM}$ Tris- $\mathrm{HCl}$ and $0.1 \mathrm{mM}$ EDTA at $\mathrm{pH}$ 8.0). The lysis buffer and TE buffer were prepared with ultrapure (NANOpure filter, Barnstead), autoclaved water. Samples were incubated at $65^{\circ} \mathrm{C}$ for 4 to $16 \mathrm{~h}$ or at $72^{\circ} \mathrm{C}$ for $2 \mathrm{~h}$. After extraction of the sample with a mixture of phenol-chloroform-isoamyl alcohol (50:48:2), DNA was precipitated with cold ethanol, pelleted by centrifugation, washed once with ethanol, and dried. Before use in the PCR, DNA was dissolved in TE buffer at $4^{\circ} \mathrm{C}$ and diluted to

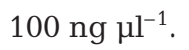

Polymerase chain reaction (PCR). We designed oligonucleotide primers to specifically amplify LMBV DNA (GenBank Accession No. AF080250); the sequence of these primers was selected to match a portion of the
LMBV genome that was distinct from the sequence of doctorfish virus and guppy virus (Mao et al. 1999). The forward primer (LMBV288F) sequence was 5'-GCG GCC AAC CAG TTT AAC GCA A-3' and the reverse primer (LMBV535R) sequence was 5'-AGG ACC CTA GCT CCT GCT TGA T-3'. The predicted location of the 248 base-pair (bp) amplified product within the major capsid protein gene (Nucleotides 288 to 535) was based on the sequence of Frog Virus 3 (FV3; Mao et al. 1996), and this location was Base Nos. 217 to 464 in GenBank Sequence AF080250. For nonspecific amplification of ranaviruses, we used a primer-pair and a method that amplified a $531 \mathrm{bp}$ segment of the major capsid protein gene of several ranaviruses (Mao et al. 1997): FV3-54F (5'-GAC TTG GCC ACT TAT GAC) and FV3-584R (5'-GTC TCT GGA GAA GAA GAA). As an internal control, we used a primer-pair that amplified a highly conserved, $632 \mathrm{bp}$ segment of the $\beta$-actin gene (GenBank Accession No. L36342): the forward primer sequence was 5'-TGC GTG ACA TCA AGG AGA AG-3' and the reverse primer sequence was 5'-AAT CCA CAT CTG CTG GAA GG-3'.

The reagents used for PCR amplification were from Roche Molecular Biochemicals except that the primers were synthesized by Invitrogen. Each $35 \mu \mathrm{l}$ reaction mixture (prepared on ice) contained $350 \mathrm{ng}$ of the sample DNA, $3.5 \mu \mathrm{l}$ of $10 \times$ PCR buffer, $2 \mathrm{mM} \mathrm{MgCl}_{2}, 0.7 \mu \mathrm{l}$ of dNTP mixture $(10 \mu \mathrm{l}$ of $100 \mathrm{mM}$ dATP, $10 \mu \mathrm{l}$ of $100 \mathrm{mM}$ dCTP, $10 \mu \mathrm{l}$ of $100 \mathrm{mM}$ dGTP, $30 \mu \mathrm{l}$ of $100 \mathrm{mM}$ dUTP, and $40 \mu \mathrm{l}$ of distilled water), $100 \mathrm{ng}$ of each primer, $7 \mu \mathrm{l}$ of $5 \times \mathrm{GC}$-rich solution, $1.2 \mathrm{U}$ of FastStart Taq polymerase, and 0.5 U UNG. The optimum concentration of $\mathrm{MgCl}_{2}$ for this reaction should be determined when the procedure or any component of the reaction mixture is altered. For the direct detection of LMBV in fishes, the PCR mixture contained the LMBV288F and LMBV535R primer-pair plus primers for $\beta$-actin. A PTC-100 thermal cycler (MJ Research) was used for the PCR as follows, Cycle 1: $20^{\circ} \mathrm{C}$ for 2 min (UNG incubation) and $95^{\circ} \mathrm{C}$ for $3 \mathrm{~min}, 15 \mathrm{~s}$; Cycles 2 to $16: 95^{\circ} \mathrm{C}$ for $45 \mathrm{~s}, 60^{\circ} \mathrm{C}$ for $45 \mathrm{~s}$, and $72^{\circ} \mathrm{C}$ for $1 \mathrm{~min}$; Cycles 17 to 36 : $95^{\circ} \mathrm{C}$ for $45 \mathrm{~s}, 60^{\circ} \mathrm{C}$ for $45 \mathrm{~s}$, and $72^{\circ} \mathrm{C}$ for 1 min plus $5 \mathrm{~s}$ for each additional cycle; Cycle 37: $72^{\circ} \mathrm{C}$ for $7 \mathrm{~min}$. Controls received the PCR mixture containing (1) no DNA template (reagent control), (2) DNA from negative control fish (negative control), or (3) DNA from LMBV (positive control). After the PCR, products were transferred to a $1.0 \%$ agarose gel, electrophoresed, and DNA was visualized by ethidium bromide staining.

Cell culture. For isolation of LMBV from fish samples, organ homogenates were centrifuged as described above and then incubated overnight at $4^{\circ} \mathrm{C}$ with an equal volume of an antibiotic incubation mixture (final concentrations were $800 \mathrm{IU} \mathrm{ml}^{-1}$ 
penicillin, $800 \mathrm{IU} \mathrm{ml}^{-1}$ streptomycin, and $20 \mu \mathrm{g} \mathrm{ml}^{-1}$ Fungizone). Bluegill Lepomis macrochirus fry (BF-2) cells were grown in 48 -well plates at $30^{\circ} \mathrm{C}$ with Eagle's minimum essential medium supplemented with $10 \%$ fetal calf serum. Cell monolayers were inoculated with $0.1 \mathrm{ml}$ of diluted sample (1:100 final dilution) and examined for cytopathic effects (CPE) daily for $7 \mathrm{~d}$. Supernatant from positive cultures was used for PCR (as described above) to confirm that cell cultures with CPE were infected with LMBV. For plaque assays, FHM cells were inoculated with diluted organ homogenate or cell-culture supernate, overlayed with methylcellulose, and the number of plaque-forming units (PFU) was calculated by a maximum-likelihood method (LaBarre \& Lowy 2001).

Determination of limit of detection by PCR. Cell culture medium was collected $24 \mathrm{~h}$ after BF-2 cells had been inoculated with LMBV. This medium was serially diluted with HBSS and used to determine the number of PFU ml $\mathrm{m}^{-1}$ of medium. The DNA was extracted from $1 \mathrm{ml}$ of each dilution, dissolved in $100 \mu \mathrm{l}$ of TE buffer, and used in the PCR method described above with the LMBV288F and LMBV535R primer-pair. The most dilute sample that was PCR-positive for LMBV was considered to be the end-point, and was used to calculate the number of PFU that could be detected by PCR.

Sequencing method. To verify that the LMBV288F535R primer-pair amplified LMBV DNA, the PCR product was purified with a QIAquick PCR purification kit (Qiagen) and directly sequenced with an ABI PRISM 3100 genetic analyzer (Applied Biosystems). Both strands of templates were sequenced. The derived nucleotide sequences were analyzed and aligned with BioEdit Sequence Alignment Editor (North Carolina State University, Raleigh, North Carolina).

\section{RESULTS AND DISCUSSION}

The LMBV288F-535R primer-pair amplified a 248 bp DNA fragment of LMBV from Santee-Cooper Reservoir but did not amplify DNA from 4 other ranaviruses or from red seabream iridovirus (Fig. 1). Included among the viruses not amplified by this primer-pair were doctorfish virus and guppy virus, which Mao et al. (1999) concluded were the same species as LMBV. The primers FV3-54F and FV3-584R designed by Mao et al. (1997) amplified DNA from all the ranaviruses tested, including LMBV, but did not amplify red seabream iridovirus (Fig. 1). The nonspecific amplification of ranaviruses by the FV3-54F and
FV3-584R primers is consistent with previous experiments with these primers (Mao et al. 1997, 1999, Bollinger et al. 1999).

The PCR method described in this report (LMBV288F-535R primer-pair) amplified a $248 \mathrm{bp}$ DNA fragment from 30 virus isolates that had been presumptively identified as LMBV based on earlier methods. These isolates were from 9 fish species (all centrarchids except for the chain pickerel Esox niger) and from 25 geographical locations in 12 states in the USA (Table 1). In addition, all fish in this study that were cell-culture positive for LMBV were also positive with the new PCR method (Fig. 2, Table 2).

For LMBV in cell-culture medium, the limit of detection for the PCR method with the LMBV288F and LMBV535R primers was $2.7 \mathrm{PFU} \mathrm{ml}^{-1}$ (Fig. 3). This is equivalent to $0.093 \mathrm{PFU}$ in the $\mathrm{PCR}$ reaction tube, since the PCR tube contained only $3.5 \mu$ of TE buffer containing the sample DNA (the total DNA extracted from each dilution was dissolved in $100 \mu$ l of TE buffer). This result could indicate that a plaque-forming unit of LMBV included several virions or that some of the LMBV DNA detected by PCR was from incompletely formed virions or other noninfective units not detected by cell culture.

The PCR method indicated that the prevalence of LMBV infection in largemouth bass from 3 reservoirs was higher than the prevalence determined by isolation of LMBV in cell culture (Table 2). Negative controls, including reagent controls and channel catfish, which were necropsied along with virus-positive largemouth bass, were PCR-negative. Neither cell culture nor PCR detected LMBV in 2 other populations of largemouth bass (Table 2).

A 632 bp segment of a $\beta$-actin gene was used as an internal control for identification of false-negative PCR results (Fig. 2). Successful amplification of this $\beta$-actin gene in samples that were negative for LMBV indi-

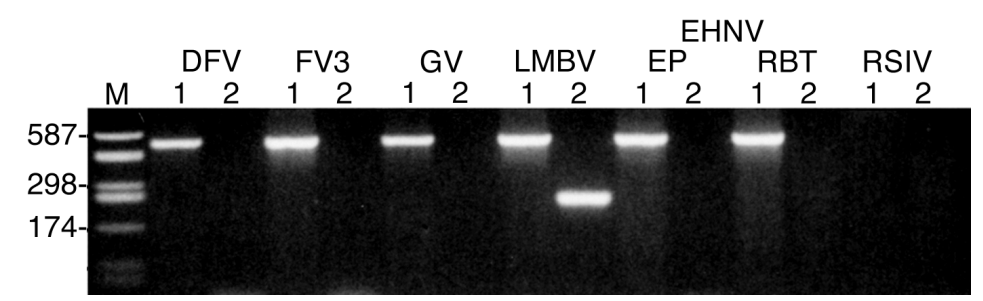

Fig. 1. Specific amplification of largemouth bass virus (LMBV) DNA by PCR, incorporating LMBV288F and LMBV535R primer-pair (lanes labeled 2; predicted size of amplified DNA fragment $=248 \mathrm{bp}$ ) compared with less specific amplification by Primers FV3-54F and FV3-584R (lanes labeled 1; predicted size of amplified DNA fragment $=531 \mathrm{bp}$ ). Viruses used for this comparison were doctorfish virus (DFV), frog virus 3 (FV3), guppy virus $(\mathrm{GV})$, largemouth bass virus (LMBV), epizootic hematopoietic necrosis virus (EHNV) from both Eurasian perch (EP) and rainbow trout (RBT), and red seabream iridovirus (RSIV). Lane $\mathrm{M}=$ molecular mass markers 
Table 1. Examples of virus isolates that were PCR-positive with the largemouth bass virus 288F-535R primer-pair. When multiple isolates from a fish species-river basin combination were tested, only 1 example is included in the table; the 1995 isolate from Santee-Cooper Reservoir was used as the positive control isolate. Largemouth bass: Micropterus salmoides; spotted bass: M. punctulatus; smallmouth bass: M. dolomieui; Suwanee bass: M. notius; bluegill: Lepomis macrochirus; redear sunfish: L. microlophus; white crappie: Pomoxis annularis; black crappie: P. nigromaculatus; chain pickerel: Esox niger. Cited studies provide additional information. WS-FWS: Warm Springs Fish Health Center, US Fish and Wildlife Service, Warm Springs, Georgia; SECFDP: Southeastern Cooperative Fish Disease Project, Auburn University, Auburn, Alabama; LC-FWS: La Crosse Fish Health Center, US Fish and Wildlife Service, Onalaska, Wisconsin; AEWFH: A.E. Wood Fish Hatchery, San Marcos, Texas

\begin{tabular}{|llll|}
\hline Year & \multicolumn{1}{c}{ Fish species } & \multicolumn{1}{c|}{ Geographical origin } & Source \\
\hline 1991 & Largemouth bass & Lake Weir, FL & Grizzle et al. (2002) \\
1995 & Largemouth bass & Santee-Cooper, SC & Plumb et al. (1996) \\
1999 & Largemouth bass & Richloam Hatchery, FL & Woodland et al. (2002) \\
1999 & Largemouth bass & Booker Fowler Hatchery, LA & Woodland et al. (2002) \\
1999 & Largemouth bass & Normandy Hatchery, TN & Woodland et al. (2002) \\
1999 & Largemouth bass & Jasper Hatchery, TX & Woodland et al. (2002) \\
1999 & Largemouth bass & Athens Hatchery, TX & Woodland et al. (2002) \\
1999 & Largemouth bass & Neuse River, NC & WS-FWS \\
1999 & Largemouth bass & Kentucky Lake, KY & WS-FWS \\
1999 & Spotted bass & Kentucky Lake, KY & WS-FWS \\
1999 & Smallmouth bass & Kentucky Lake, KY & WS-FWS \\
1999 & Suwanee bass & Wacissa River, FL & WS-FWS \\
1999 & Bluegill & Lake Talquin, FL & WS-FWS \\
1999 & Redear sunfish & Atchafalaya River, LA & WS-FWS \\
1999 & White crappie & Atchafalaya River, LA & WS-FWS \\
1999 & Black crappie & Atchafalaya River, LA & WS-FWS \\
2000 & Largemouth bass & Lake Bruin, LA & SECFDP \\
2000 & Largemouth bass & Lake George, MI & LC-FWS \\
2000 & Largemouth bass & Wappapello Lake, MO & LC-FWS \\
2001 & Smallmouth bass & A.E. Wood Hatchery, TX & AEWFH \\
2001 & Largemouth bass & Lake Springfield, MO & SECFDP \\
2001 & Largemouth bass & Hamilton Lake, IN & SECFDP \\
2001 & Chain pickerel & Lake Horton, GA & SECFDP \\
2001 & Largemouth bass & W.F. George Reservoir, AL/GA & SECFDP \\
2001 & Largemouth bass & Wheeler Reservoir, AL & SECFDP \\
& & & \\
\hline
\end{tabular}

cated that inhibitors did not prevent the PCR, that the sample DNA quality was satisfactory for PCR, and that the DNA template was not accidentally omitted from the PCR reaction. Negative results for the internal con-

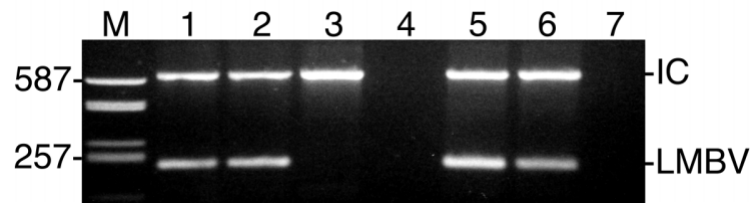

Fig. 2. Micropterus salmoides. Detection by PCR of LMBV in largemouth bass. LMBV288F and LMBV535R primer-pair amplified a 248 bp DNA fragment (LMBV) from the LMBVpositive control (Lane 6) and from largemouth bass that were cell-culture positive for virus (Lanes 1 and 2). Lane 5 contained a sample from a largemouth bass that was cell culture negative but was PCR-positive. As an internal control (IC), a second primer-pair was used to amplify a $632 \mathrm{bp}$ DNA fragment of the $\beta$-actin gene; Lane 4 contained a false-negative sample from a largemouth bass, Lane 3 a sample from a virus-negative largemouth bass, while Lane 7 was a negative control containing

$\mathrm{PCR}$ reagents alone. Lane $\mathrm{M}=$ molecular mass markers trol indicated that the sample was faulty (Fig. 2). When sufficient homogenized tissue was available from samples that were initially negative for $\beta$-actin DNA, additional DNA isolated from these samples usually resulted in satisfactory PCR results.

The lack of positive PCR results for samples from locations where all of the largemouth bass were cell-

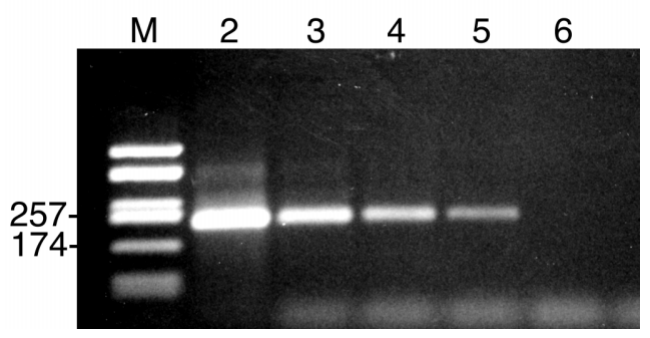

Fig. 3. Detection by PCR (LMBV288F and LMBV535R primers) of LMBV in cell-culture medium serially diluted with Hanks' balanced salt solution. Lane $1=$ molecular mass markers, and Lanes 2 to $6=10^{-2}$ to $10^{-6}$ dilutions, respectively. Undiluted medium contained $2.7 \times 10^{-5} \mathrm{PFU} \mathrm{ml}{ }^{-1}$, and the $10^{5}$ dilution was the most dilute sample that was PCR-positive for LMBV 
Table 2. Micropterus salmoides. Detection of LMBV in largemouth bass. Same sample of homogenized organs (pooled spleen, swim bladder, and trunk kidney) was used for cell culture and for PCR. Primers used for PCR were LMBV288F and LMBV535R

\begin{tabular}{|c|c|c|c|c|c|}
\hline Source of fish & $\begin{array}{c}\text { Collection } \\
\text { date } \\
(2001)\end{array}$ & PCR+ & $\begin{array}{l}\text { Cell } \\
+ \\
\text { PCR }\end{array}$ & $\begin{array}{l}\text { ulture } \\
\text { PCR+ }\end{array}$ & - \\
\hline Wheeler Reservoir, AL & $30 \mathrm{Jul}$ & 11 & 0 & 37 & 36 \\
\hline Wheeler Reservoir, AL & $13 \mathrm{Sep}$ & 3 & 0 & 16 & 11 \\
\hline Wheeler Reservoir, AL & $5 \mathrm{Nov}$ & 3 & 0 & 9 & 34 \\
\hline Guntersville Res., AL & 16 Oct & 6 & 0 & 20 & 27 \\
\hline W.F. George Res., AL/GA & 10 Oct & 7 & 0 & 14 & 32 \\
\hline Lee County Lake, AL & $15 \mathrm{Nov}$ & 0 & 0 & 0 & 61 \\
\hline Cox Hollow Lake, WI & $6 \mathrm{Nov}$ & 0 & 0 & 0 & 20 \\
\hline
\end{tabular}

culture negative (Table 2) suggests that our PCR method does not have a high rate of false positives. To further confirm that the positive PCR results occurred because LMBV DNA was present in the samples, we sequenced the amplified DNA product (248 bp) from 6 fish and found that the amplified fragment exactly matched the sequence of LMBV DNA (GenBank Accession No. AF080250).

Although the PCR method detects a lower amount of virus than detected by cell culture, the relative sensitivity of these methods depends on the amount of virus present in the organs sampled. When the virus titer is high, as reported for diseased largemouth bass (Plumb et al. 1996), the cell-culture method is likely to detect a larger proportion of the infected individuals than when the virus titer is low, which occurs in subclinically infected fish (Woodland et al. 2002). Because the sensitivity of the cell-culture method is likely to vary depending on the population of fish tested, maximum likelihood estimation and Bayesian inference methods used to calculate sensitivity and specificity of pathogen detection methods are likely to provide invalid results (Enøe et al. 2000).

The PCR method described in the present paper provides improved capabilities to detect LMBV in subclinically infected fish. However, the detection of low levels of virus by the PCR method is not important for the diagnosis of the disease caused by LMBV because of the high titers present in clinically ill largemouth bass. The low detection limit of our PCR method is a potential problem unless adequate safeguards, as described in the foregoing methods, are used in avoiding sample contamination. The specific amplification by the LMBV288F-535R primer-pair may be useful to avoid misidentification of other iridoviruses as LMBV. This is important for both primary detection of LMBV in fish by PCR and for identification of the virus isolated in cell culture.
Acknowledgements. This project was funded by Sport Fish Restoration Funds administered through the Alabama Cooperative Fish and Wildlife Research Unit. We thank E. Irwin for assistance with project administration. Additional funding was from the Southeastern Cooperative Fish Disease Project. Isolates of LMBV were provided by W. Fraser, Florida Department of Agriculture and Consumer Service, Kissimmee, Florida; N. Heil, Warm Springs Fish Health Center, US Fish and Wildlife Service, Warm Springs, Georgia; B. Lasee, La Crosse Fish Health Center, US Fish and Wildlife Service, Onalaska, Wisconsin; and L. Fries, A. E. Wood Fish Hatchery, San Marcos, Texas. Samples of other viruses were provided by V. G. Chinchar, University of Mississippi Medical Center, and H. Fukuda, Tokyo University of Fisheries. Fish or organ samples were provided by M. J. Maceina, Auburn University; J. McHugh, Alabama Division of Wildlife and Freshwater Fisheries; S. Syska, Missouri Department of Conservation, Springfield, Missouri; R. White, Purdue University, West Lafayette, Indiana; and B. Lasee, La Crosse Fish Health Center. K. Hayden, S. Cooper, T. Henry, B. Beck, S. Sranton, and M. Smith assisted with necropsy, cell culture, and PCR. The manuscript was reviewed by J. Plumb, N. Heil, and C. Brunner.

\section{LITERATURE CITED}

Bollinger TK, Mao JH, Schock D, Brigham RM, Chinchar VG (1999) Pathology, isolation, and preliminary molecular characterization of a novel iridovirus from tiger salamanders in Saskatchewan. J Wildl Dis 35:413-429

Enøe C, Georgiadis MP, Johnson WO (2000) Estimation of sensitivity and specificity of diagnostic tests and disease prevalence when the true disease state is unknown. Prev Vet Med 45:61-81

Grizzle JM, Altinok I, Fraser WA, Francis-Floyd R (2002) First isolation of largemouth bass virus. Dis Aquat Org 50: 233-235

Hanson LA, Petrie-Hanson L, Meals KO, Chinchar VG, Rudis $M$ (2001) Persistence of largemouth bass virus infection in a northern Mississippi reservoir after a die-off. J Aquat Anim Health 13:27-34

LaBarre DD, Lowy RJ (2001) Improvements in methods for calculating virus titer estimates from $\mathrm{TCID}_{50}$ and plaque assays. J Virol Methods 96:107-126

Mao J, Tham N, Gentry GA, Aubertin A, Chinchar VG (1996) Cloning, sequence analysis, and expression of the major capsid protein of the iridovirus frog virus 3. Virology 216: 431-436

Mao J, Hedrick RP, Chinchar VG (1997) Molecular characterization, sequence analysis, and taxonomic position of newly isolated fish iridoviruses. Virology 229:212-220

Mao J, Wang J, Chinchar GD, Chinchar VG (1999) Molecular characterization of a ranavirus isolated from largemouth bass Micropterus salmoides. Dis Aquat Org 37:107-114

Plumb JA, Grizzle JM, Young HE, Noyes AD, Lamprecht S (1996) An iridovirus isolated from wild largemouth bass. J Aquat Anim Health 8:265-270

Plumb JA, Noyes AD, Graziano S, Wang J, Mao J, Chinchar VG (1999) Isolation and identification of viruses from adult largemouth bass during a 1997-1998 survey in the southeastern United States. J Aquat Anim Health 11:391-399

Woodland JE, Noyes AD, Grizzle JM (2002) A survey to detect largemouth bass virus among fish from hatcheries in the southeastern USA. Trans Am Fish Soc 131:308-311

Zilberg D, Grizzle JM, Plumb JA (2000) Preliminary description of lesions in juvenile largemouth bass injected with largemouth bass virus. Dis Aquat Org 39:143-146

Submitted: June 20, 2002; Accepted: November 20, 2002

Proofs received from author(s): February 21, 2003 